\title{
Variation of sponge-inhabiting infauna with the state of health of the sponge Lubomirskia baikalensis (Pallas, 1776) in Lake Baikal
}

\author{
Yulia Zvereva ${ }^{1}$ (1) - Olga Medvezhonkova ${ }^{1} \cdot$ Tatyana Naumova $^{1} \cdot$ Natalia Sheveleva ${ }^{1} \cdot$ Anton Lukhnev $^{1}$. \\ Ekaterina Sorokovikova' ${ }^{1}$ Taisia Evstigneeva ${ }^{1}$. Oleg Timoshkin ${ }^{1}$
}

Received: 14 May 2018 / Accepted: 19 March 2019 / Published online: 5 April 2019

(c) The Japanese Society of Limnology 2019

\begin{abstract}
Our investigation was conducted during a period of ecological crisis in the coastal zone of Lake Baikal. Mass disease and mortality of the endemic sponges inhabiting the nearshore zone of the lake is one of the characteristics of this crisis. We identified and quantified infaunal organisms associated with Lubomirskia baikalensis (Pallas, 1776), which is experiencing mass morbidity and mortality. L. baikalensis specimens were subdivided into three groups depending on the degree of body damage they presented: "healthy", diseased, or dead. We found that infauna was almost absent from "healthy" sponges. Infaunal abundance in diseased sponges was 1820 times greater than that in "healthy" sponges, and varied in relation to the type of damage suffered by the sponges. Unaffected fragments of diseased sponges were inhabited by communities that exhibited an average abundance of $13 \mathrm{ind} / \mathrm{dm}^{2}$, with Oligochaeta, Nematoda, Harpacticoida, and Chironomidae predominating. In the bleached fragments of morbid sponges, the average abundance of infauna was $1303 \mathrm{ind} / \mathrm{dm}^{2}$, with Harpacticoida, Tardigrada, Cyclopoida, and Oligochaeta dominating. The highest concentration of infaunal animals $\left(18,293 \mathrm{ind} / \mathrm{dm}^{2}\right)$ was observed in spots that were covered by filamentous cyanobacteria. Diverse and densely populated infaunal communities ( $4767 \mathrm{ind} / \mathrm{dm}^{2}$ ) occurred in the dead sponges, with Nematoda, Tardigrada, Turbellaria, and Oligochaeta particularly abundant.
\end{abstract}

Keywords Sponge deterioration and mortality $\cdot$ Freshwater sponge consortium $\cdot$ Ecological crisis $\cdot$ Lubomirskiidae $\cdot$ Spongillina $\cdot$ Lake Baikal

\section{Introduction}

There are 238 known species of freshwater sponges (Spongillina), and they are widespread in lentic and lotic waters (Manconi and Pronzato 2015). One of the Spongillina families, Lubomirskiidae (4 genera, 15 species), has an extremely restricted geographic distribution (Efremova 2001; Manconi and Pronzato 2008, 2015). Members of the family are found only in Lake Baikal, the most ancient and deepest lake in the world, situated in the central part of Asia. Lake Baikal could be called "the lake of sponges" due to the

Handling Editor: Fabio Lepori.

Yulia Zvereva

zvereva@lin.irk.ru

1 Laboratory of Aquatic Invertebrate Biology, Limnological Institute, Siberian Branch of the Russian Academy of Sciences (LIN SB RAS), Ulan-Batorskaya st 3, Irkutsk 664033, Russia abundance and species richness of the endemic Lubomirskiidae sponges and the important ecological role they play in the littoral benthic communities (Semiturkina et al. 2009). In the lake, these animals demonstrate an amazing variety of body structures. Their growth forms can be branched, globular, or encrusting, and sizes range from $1.5-2 \mathrm{~cm}$ to $1 \mathrm{~m}$. In the recent past, these animals were very abundant and substantially affected the composition of the lake's underwater landscapes. Until mid-2000 (during the so-called pre-crisis period), encrusting sponges covered almost $100 \%$ of the bottom area of some coastal zone regions of the lake (Semiturkina et al. 2009).

A sponge is a biogenic substrate that shelters a rich and diverse fauna which presents various types of associations, including commensalism, mutualism, and parasitism (Kharchenko et al. 1989; Kamaltynov et al. 1993; Manconi and Pronzato 2008, 2015; Leite et al. 2016). Healthy freshwater sponges harbor the following animal groups: Cnidaria, Rotifera, Turbellaria, Nematoda, Oligochaeta, Hirudinea, Mollusca, Bryozoa, Hydrachnida, Crustacea, and different 
orders of Insecta (Rezvoy 1936; Konopacka and Siciński 1985; Trylis 1997; Gugel 2001; Gaino et al. 2004; Fusari et al. 2012; Boltruszko and Ejsmont-Karabin 2013; Manconi and Pronzato 2015). Associated animals can live on the sponge surface (epibionts), swim around its body (nectobionts), or live inside the sponge body (infauna).

Kozhov $(1931,1963)$ was the first to provide a detailed description of the fauna of the lake's stony littoral zone, including some data on the sponges' consortia. Kamaltynov et al. (1993) reported the first quantitative data on the branched sponge consortium in the lake and examined the dependence of the abundance of associated organisms on sponge biomass. Weinberg et al. (2003) investigated the relationships between the Baikalian sponges and their associated organisms, some of which turned out to be obligatory inhabitants. Thus, until now, there have been only two quantitative studies on the healthy consortium within Lubomirskia baikalensis (Pallas, 1776). ${ }^{1}$

The endemic sponges of Lake Baikal have recently attracted considerable interest from ecologists. The main reason for this is not their uniqueness but their large-scale demise in the coastal zone of the lake. Within the last 6 years, mass mortality and morbidity of endemic Lubomirskiidae sponges has been reported. According to Timoshkin et al. (2016), 30-100\% of branched L. baikalensis specimens were found to be diseased, damaged, or dead during the period 2014-2015, depending on the location. Diseased Baikalian sponges are occurring lakewide, and all three growth forms can be affected (Timoshkin et al. 2016; Khanaev et al. 2018).

The deterioration of the sponges is accompanied by the mass development of epizoic cyanobacteria. At present, up to 20 species of cyanobacteria were discovered on the diseased sponges. Interestingly, producers of dangerous microcystins and paralytic shellfish toxins were found among them (Belykh et al. 2016, 2017). Filamentous cyanobacteria, together with diatom algae, tend to form foulings and slimy biofilms on damaged parts of the sponge body (Timoshkin et al. 2016). Such reddish-brown patches on the sponge surface are a main symptom of brown rot syndrome (Kulakova et al. 2017), recently described for Baikalian sponges. Specialists agree that the cyanobacterial films on Baikalian sponges are probably a response to disease, but not its cause (Khanaev et al. 2018).

Although consequences of the ecological crisis in the coastal zone of Lake Baikal are evident, potential causes are still being discussed. One of the most widely supported points of view hypothesizes that nutrient enrichment from human sewage is the main cause of such dramatic changes

\footnotetext{
1 We use Lubomirskia baikalensis (Pallas, 1776) as a valid name for the species in accord with Van Soest et al. (2012).
}

at many coastal sites of the lake (Kravtsova et al. 2014; Timoshkin et al. 2014, 2016, 2018; Khanaev et al. 2018). The current situation is reminiscent of the cultural eutrophication that occurred in the Laurentian Great Lakes from the late 1950s through the early 1970s. Nonetheless, ecological degradation of the nearshore zone of Lake Baikal may have multiple drivers, including lake level fluctuations (Zohary and Ostrovsky 2011), the input of toxic industrial contaminants (e.g., organochlorine pesticides) (Mamontov et al. 2000), and climate warming (Moore et al. 2009; Izmest'eva et al. 2016).

At present, the cause of the sponges' morbidity and mortality is unknown. An infectious disease agent or unfavorable changes in environmental conditions could be a supposed cause of the disease. For example, it was suggested that an increase in the methane concentration in the water column of Lake Baikal may have caused changes in the algal endosymbionts (zoochlorellae) of the branched sponges, resulting in the mass deterioration and death of the sponges (Denikina et al. 2016). For brevity, we use "diseased" throughout this paper to distinguish healthy from unhealthy sponges.

The purpose of our paper is to determine whether and how invertebrate communities associated with the branched Baikal sponge (L. baikalensis) respond to changes in the health status of the sponge. This study is the first to characterize the succession of invertebrates in lubomirskiid sponges transiting from "healthy" through unhealthy to the dead ones. As a first step, our work focused on the meiofauna dwelling inside the sponge body (infauna).

\section{Materials and methods}

Sampling was carried out quarterly from December 2015 through September 2016 (December 2015, March, June, September 2016) at two stations located in the southern basin of Lake Baikal (Fig. 1) near Cape Berezovy $\left(51^{\circ} 30^{\prime} 11^{\prime \prime} \mathrm{N}, 104^{\circ} 32^{\prime} 33^{\prime \prime} \mathrm{E}\right)$ and Chernaya Bay $\left(51^{\circ} 31^{\prime} 53^{\prime \prime} \mathrm{N}\right.$, $\left.105^{\circ} 03^{\prime} 7^{\prime \prime} \mathrm{E}\right)$. A total of 31 sponge specimens were collected by SCUBA divers from depths ranging between 5 and $9 \mathrm{~m}$ (Table 2). Divers covered each sponge with a cloth bag of $74-\mu \mathrm{m}$ mesh to prevent the escape of fast-moving associates (mainly crustaceans). Then the sponge was removed from the substratum and the bag was sealed. On the research vessel, each sponge specimen was rinsed in lake water to remove all animals living on the sponge surface (epibionts and nectobionts). This water and the water from each cloth bag were sieved and fixed in $10 \%$ formalin (every sponge was treated as a separate sample) and stored for future use. The samples of epi- and nectobionts will be the focus of future study and were not considered in the present paper. 


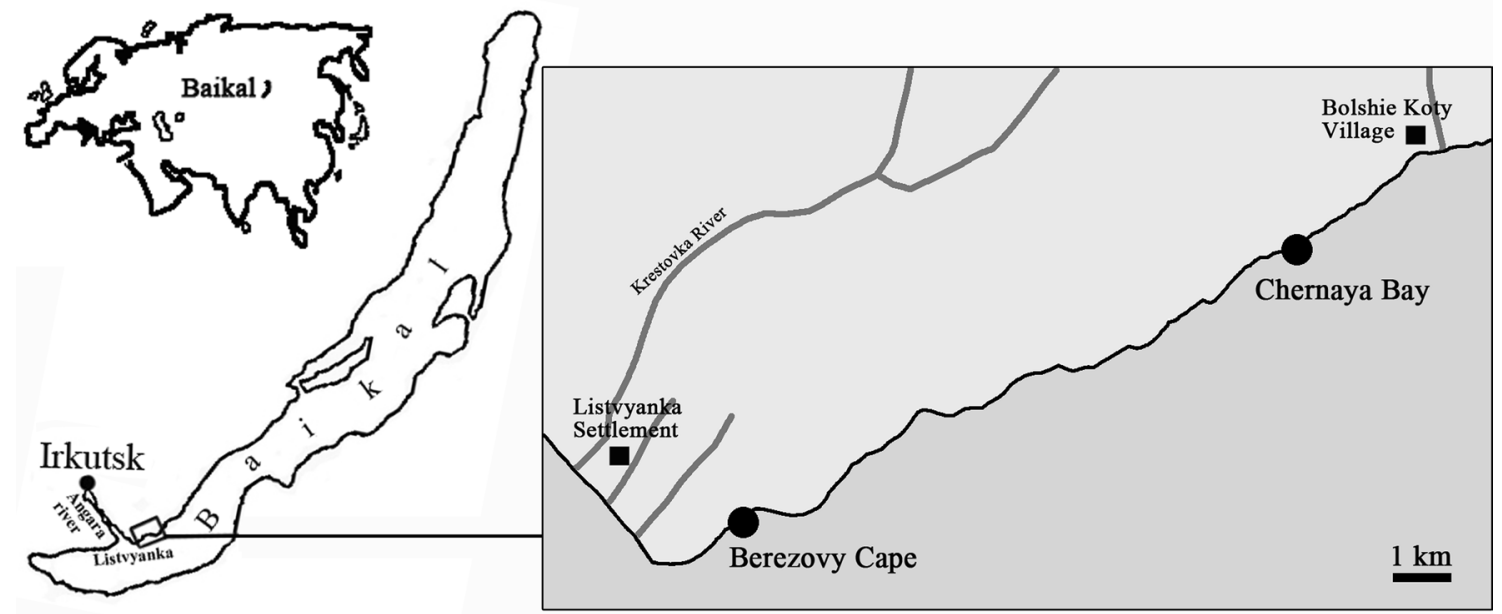

Fig. 1 Locations of sponge sampling sites (black dots) in the southern basin of Lake Baikal

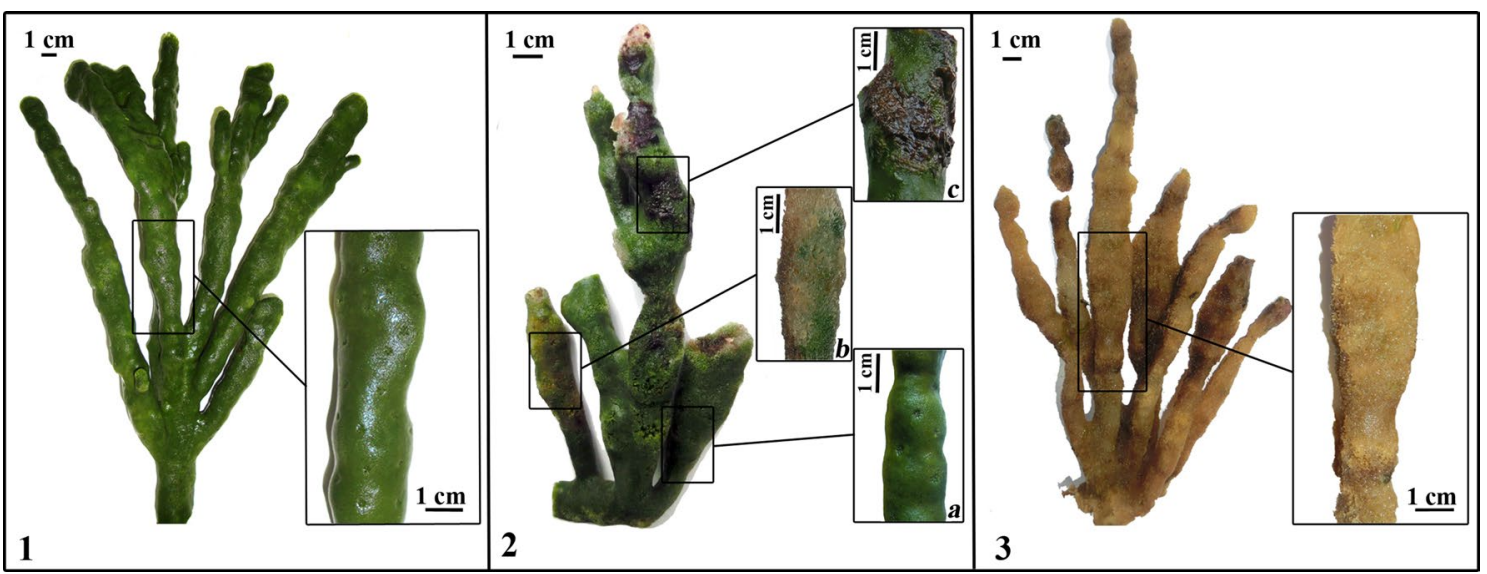

Fig. 2 Different states of health of branched sponge L. baikalensis individuals. 1 A "healthy" sponge. 2 A diseased sponge ( $a$ unaffected fragments, $b$ bleached fragments, $c$ fragments covered by a fouling or biofilm). $3 \mathrm{~A}$ dead sponge

Soon after sampling, we chose small fragments of sponge body that we would use to study the infauna. Chosen fragments were removed, photographed, weighed, and fixed in $70 \%$ ethanol. Before estimating the abundance of infauna in the sponges, we first classified each L. baikalensis specimen as "healthy", diseased, or dead. The typical color of healthy L. baikalensis is bright green (Rezvoy 1936; Kozhov 1963). Therefore, a sponge was considered "healthy" if it had a bright green body and the absence of any damage, tissue bleaching, patches, cyanobacterial foulings, or other atypical films (Fig. 2.1). If the sponge color differed from green and the features above were present, the sponge was considered to be diseased (Fig. 2.2). If we observed necrotic areas on the sponge body and it had a brownish color (signs of decay) or foulings/biofilms on the surface, the sponge was considered dead (Fig. 2.3). It should be noted that, at present, even sponges that look green and vigorous cannot be considered to be truly healthy, so we considered them to be relatively "healthy".

We chose random fragments on different parts of the branches (apical, middle, and basal) of "healthy" and dead sponges. From diseased sponges, we cut off fragments and classified them as either (a) unaffected, (b) bleached (sponge fragments with destroyed tissue and without colorful endosymbionts), or (c) covered by a fouling or biofilm (Fig. 2.2). Biofilms were classified as one- or two-layered coverings formed by diatom algae and cyanobacteria. Foulings consisted of mats of filamentous cyanobacteria. In the laboratory, we carefully macerated sponge fragments and collected all the meiobenthic animals under a stereomicroscope. In this work, the term "meiobenthos" denotes an assemblage of motile bottom aquatic animals (small metazoans and large protozoans) with body lengths ranging from $0.3 \mathrm{~mm}$ up to $4 \mathrm{~mm}$ (after Kurashov 1994). Organisms were identified 
to the lowest practical taxonomic level and stored in $70 \%$ ethanol. To identify animal species and cyanobacteria, we used a compound microscope ( $4 \times, 10 \times, 40 \times$ magnification) and up-to-date guides and keys (Semernoy 2004; Komárek and Anagnostidis 2005). Sörensen's distance was used to compare the degree of similarity of species assemblages inhabiting sponges in different states of health (Shitikov et al. 2003). A taxonomic group or species was characterized as dominant if its contribution to the total abundance was higher than 5\% (Lazareva 1997). The number of individuals was standardized to $1 \mathrm{dm}^{2}$ of sponge surface (mean \pm standard error of mean), as most of the animals inhabited nearsurface layers of the sponge body. The area of the sponge surface was computed from photos using the program Image-Pro Plus 7.0. Only part of the data (33 samples) were calculated for $100 \mathrm{~g}$ of wet sponge (Table 2) to permit comparison with the results of Kamaltynov et al. (1993), who quantified the fauna associated with absolutely healthy $L$. baikalensis during the pre-crisis period.

\section{Results and discussion}

\section{Biodiversity}

The sponge body acts as a fairly stable biotope, providing its inhabitants with favorable conditions for their development and reproduction. Fauna associated with freshwater sponges includes many taxa (Manconi and Pronzato 2015). The same is true for the Baikalian branched sponge, L. baikalensis (Kamaltynov et al. 1993; Weinberg et al. 2003). In the case of infauna, only scarce oligochaetes Nais sp. and a cyclopoid copepod, A. spongicola (found exclusively in sponge oscula) were noted previously inside healthy individuals of $L$. baikalensis (Kamaltynov et al. 1993).

Infaunal associates of L. baikalensis in different states of health belonged to 12 taxonomic groups (Table 1). We only found representatives of Nematoda and Oligochaeta in the bodies of "healthy" sponges. In contrast, infaunal communities of diseased and dead sponges were taxonomically richer, and they included all 12 taxa, with Nematoda, Tardigrada, Oligochaeta, and Crustacea dominating in terms of abundance. Interestingly, the groups Rotifera and Tardigrada were observed among associated fauna (including epi- and nectofauna) for the first time.

In our study, 53 taxa in total were recorded for L. baikalensis infauna (Table 1). More infaunal taxa were observed in diseased (40 taxa) than in dead (31 taxa) sponges. The fauna of "healthy" L. baikalensis was distinctly different from those of diseased and dead sponges (5 and 6\% similarity, respectively, using Sörensen's index). In contrast, the faunas of diseased and dead sponges had a high value of similarity (58\% with Sörensen's index). "Diseased sponges" was quite a heterogeneous group, as each diseased sponge specimen exhibited different types of damage (Figs. 2.2, 4). That is why we also compared the taxonomic compositions of unaffected fragments, bleached fragments, and foulingcovered fragments of diseased sponges. Sörensen's index showed that the fauna of the unaffected fragments was most similar to that of "healthy" sponges' ( $25 \%$ similarity), but the faunas of bleached fragments and fouling-covered fragments were most similar to each other (50\% similarity). We also found that faunas of dead sponges and the bleached fragments of diseased sponges (54\%) were the most similar according to Sörensen's index.

Lubomirskia baikalensis infauna appears to be less diverse than that of Spongillidae representatives belonging to the other family of freshwater sponges, which is cosmopolitan. Konopacka and Siciński (1985) found 17 taxonomic groups represented by 74 species of macrofauna associated with Spongillidae in the River Gać. Such rich biodiversity of faunal associates in Spongillidae is largely the result of the presence of different orders of Insecta (Gugel 2001; Gaino et al. 2004; Sokolova and Palatov 2014) in these sponges. The same authors also noted that "dead" colonies (i.e., colonies in a state of anabiosis) of these sponges contained more taxonomic groups than did living colonies. Such a situation is similar to that which we have reported for the infauna of dead L. baikalensis. The main difference is that dead colonies are a natural part of the life cycle of Spongillidae, but not for Lubomirskiidae.

\section{Infauna of "healthy" L. baikalensis: density and composition}

The occurrence of invertebrates inside the sponge body is common for freshwater Spongillidae. Some typical infaunal associates of Spongilla have been known for a long time (e.g., neuropterans Sisyra, trichopterans Leptocerus and Ceraclea, chironomids, and hydrachnids Unionicola) (Rezvoy 1936). In contrast, only a few specimens of Nematoda and Oligochaeta were found inside the bodies of "healthy" L. baikalensis sponges (Table 2, Fig. 3).

Differences in body structure between lubomirskiid and spongillid sponges may explain the disparity between their infaunal assemblages. The body of a healthy L. baikalensis is firm and rubbery with a well-developed dermal membrane and a strong skeleton (Rezvoy 1936). Only certain amphipods of the genus Eulimnogammarus are able to gnaw holes into the body of L. baikalensis (Rezvoy 1936; Kamaltynov et al. 1993; Weinberg et al. 2003). For Spongillidae, oligochaetes and various insect larvae can easily carve their way inside the sponge body and use it as a food source and building material (Rezvoy 1936; Gaino et al. 2004).

Therefore, the present study confirms that there is a very low abundance of infaunal invertebrates inside "healthy" 
Table 1 List of dominant infaunal species within endemic L. baikalensis sponges in different states of health: "healthy", diseased (a: unaffected fragments of the diseased sponges; $b$ : bleached fragments; c: fragments covered by foulings/biofilms), and dead

Taxa

"Healthy"

Diseased

Dead

a b c

Ciliophora

Turbellaria

Macrostomum sp.

Baikalobia copulatrix (Korotneff, 1912)

Geocentrophora sp.

Opisthocystis angarensis (Sibirjakova, 1929)

Opisthocystis sp. (sabussovi ?)

Gyratrix hermaphroditus Ehrenberg, 1831

Dalyellioida sp.

Kalyptorhynchia sp.

Nematoda

Tobrilus saprophagus Naumova et Gagarin, 2017

Tobrilus sp. 1

Tobrilus sp. 2

Eutobrilus sp.

Tripyla sp.

Monhystera paludicola de Man, 1881

Eumonhystera filiformis (Bastian, 1865)

Ethmolaimus pratensis de Man, 1880

E. pilosus Shoshin, 1998

Allodiplogaster mordax (Shoshin, 1989)

Allodiplogaster $\mathrm{sp}$.

Oligochaeta

Machetna koshovi (Sokolskaya, 1962)

Machetna sp.

Nais baicalensis Sokolskaja, 1962

N. similis Semernoy, 1984

N. tatijanae Semernoy, 1984

Chaetogaster diaphanus litoralis Semernoy, 1985

Ch. paucus Semernoy, 1985

Ch. cf. crocodilus, Semernoy, 1985

Ch. gavrilovi Semernoy, 1985

Tubificidae gen. sp. juv.

Enchytraeidae gen. sp. juv.

\section{Rotifera}

Filinia terminalis (Plate, 1886)

Lecane bulla (Gosse, 1886)

L. lunaris (Ehrenberg, 1832)

Euchlanis ligulata Kutikova et Vassiljeva, 1982

Dicranophorus sp.

Bdelloidae gen. sp.

\section{Harpacticoida}

Harpacticella inopinata Sars, 1908

Bryocamptus (Rheocamptus) rylovi Borutzky, 1931

B. (Rh.) baikalensis Borutzky, 1931

B. (Rh.) denticulatus Borutzky et Okuneva, 1972

Attheyella (Ryloviella) baikalensis Borutzky, 1931

Moraria schmeily van Douwe, 1903

Canthocamptus (Canthocamptus) gibba Okuneva, 1983
$-$

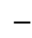

$-$

$-$

-

$+$

$-$

$+$

-

$-$

c

\begin{tabular}{|c|c|c|c|}
\hline- & - & + & ++ \\
\hline- & - & + & - \\
\hline- & + & - & - \\
\hline- & - & - & + \\
\hline- & - & - & + \\
\hline- & - & + & ++ \\
\hline- & - & - & + \\
\hline- & - & + & + \\
\hline- & + & - & ++ \\
\hline- & - & + & - \\
\hline- & - & - & - \\
\hline++ & + & ++ & - \\
\hline- & - & - & - \\
\hline- & + & - & + \\
\hline- & - & - & + \\
\hline- & - & + & - \\
\hline- & - & - & + \\
\hline- & - & - & ++ \\
\hline- & - & - & + \\
\hline- & + & - & - \\
\hline+ & + & - & + \\
\hline- & + & - & + \\
\hline- & ++ & - & ++ \\
\hline- & ++ & - & ++ \\
\hline- & ++ & - & + \\
\hline- & + & - & + \\
\hline- & + & - & - \\
\hline++ & + & + & + \\
\hline- & - & $+^{\mathrm{a}}$ & - \\
\hline$+^{\mathrm{a}}$ & - & - & - \\
\hline- & - & - & + \\
\hline- & + & + & - \\
\hline- & + & - & - \\
\hline- & + & - & - \\
\hline- & + & + & - \\
\hline- & + & + & + \\
\hline- & ++ & - & - \\
\hline- & + & + & + \\
\hline++ & ++ & + & - \\
\hline- & - & ++ & + \\
\hline- & - & + & - \\
\hline- & + & - & - \\
\hline- & + & ++ & - \\
\hline
\end{tabular}


Table 1 (continued)

\begin{tabular}{|c|c|c|c|c|c|}
\hline \multirow[t]{2}{*}{ Taxa } & \multirow[t]{2}{*}{ "Healthy" } & \multicolumn{3}{|c|}{ Diseased } & \multirow[t]{2}{*}{ Dead } \\
\hline & & $\mathrm{a}$ & $\mathrm{b}$ & $\mathrm{c}$ & \\
\hline Echinocamptus (Limocamptus) baicalensis Borutzky, 1931 & - & - & + & - & - \\
\hline \multicolumn{6}{|l|}{ Cyclopoida } \\
\hline Acanthocyclops galbinus Mazepova, 1962 & - & - & ++ & + & + \\
\hline A. spongicola Mazepova, 1962 & - & - & - & $+^{\mathrm{a}}$ & - \\
\hline \multicolumn{6}{|l|}{ Cladocera } \\
\hline Alona labrosa Vasiljeva et Smirnov, 1969 & - & - & + & - & + \\
\hline Amphipoda & - & - & + & + & + \\
\hline Ostracoda & - & - & + & + & + \\
\hline Chironomidae & - & + & + & ++ & + \\
\hline \multicolumn{6}{|l|}{ Tardigrada } \\
\hline Mixibius sp. & - & - & ++ & ++ & ++ \\
\hline Isohypsibius cf. baicalensis & - & - & - & - & + \\
\hline
\end{tabular}

Nematodes were identified mostly to genus level because of the predominance of juvenile specimens and the lack of mature nematodes

Two "+" symbols indicate a dominant taxon

aRare specimen

Table 2 Average abundance of infauna for L. baikalensis sponges in different states of health

\begin{tabular}{lccccc}
\hline & $\begin{array}{l}\text { No. of } \\
\text { sponge } \\
\text { speci- } \\
\text { mens }\end{array}$ & \multicolumn{4}{l}{ Average infaunal abundance } \\
\cline { 3 - 6 } & ind/dm & $\begin{array}{l}\text { No. of } \\
\text { sam- } \\
\text { ples }\end{array}$ & ind $/ 100 \mathrm{~g}$ & $\begin{array}{l}\text { No. of } \\
\text { sam- } \\
\text { ples }\end{array}$ \\
\hline "Healthy" & 5 & $3 \pm 2$ & 16 & $8 \pm 4$ & 16 \\
Diseased & 22 & $5461 \pm 1496$ & 58 & $167 \pm 85$ & 15 \\
Dead & 4 & $4767 \pm 2174$ & 9 & $5442 \pm 1608$ & 2 \\
\hline
\end{tabular}

L. baikalensis sponges ( $5 \pm 4$ ind. per $100 \mathrm{~g}$ wet sponge weight). This is similar to previous data obtained for Baikalian sponges during the pre-crisis period (Kamaltynov et al. 1993). It is likely that a few nematodes and oligochaetes inhabit the L. baikalensis body where the sponge surface experiences normal, low-level damage (scratches, cracks, cavities). Consequently, rich and abundant infauna is uncharacteristic of absolutely healthy $L$. baikalensis.

\section{"Healthy" sponges Diseased sponges Dead sponges}

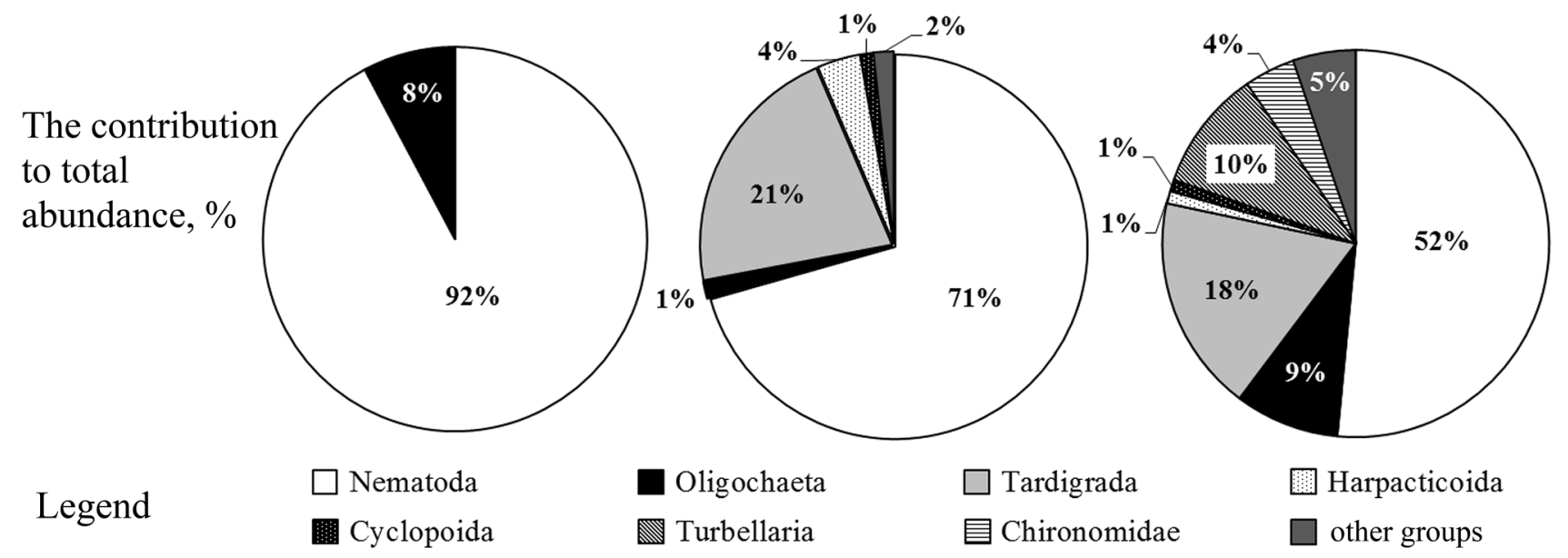

Fig. 3 The contributions of different taxonomic groups to the total infaunal abundances in "healthy", diseased, and dead L. baikalensis sponges 
Fig. 4 The average abundances and percentages of infaunal animals residing in diseased $L$. baikalensis sponges presenting different damage types: a unaffected fragments, $\mathbf{b}$ bleached fragments, $\mathbf{c}$ fragments covered by a fouling or biofilm. The scale bars equal $1 \mathrm{~cm}$
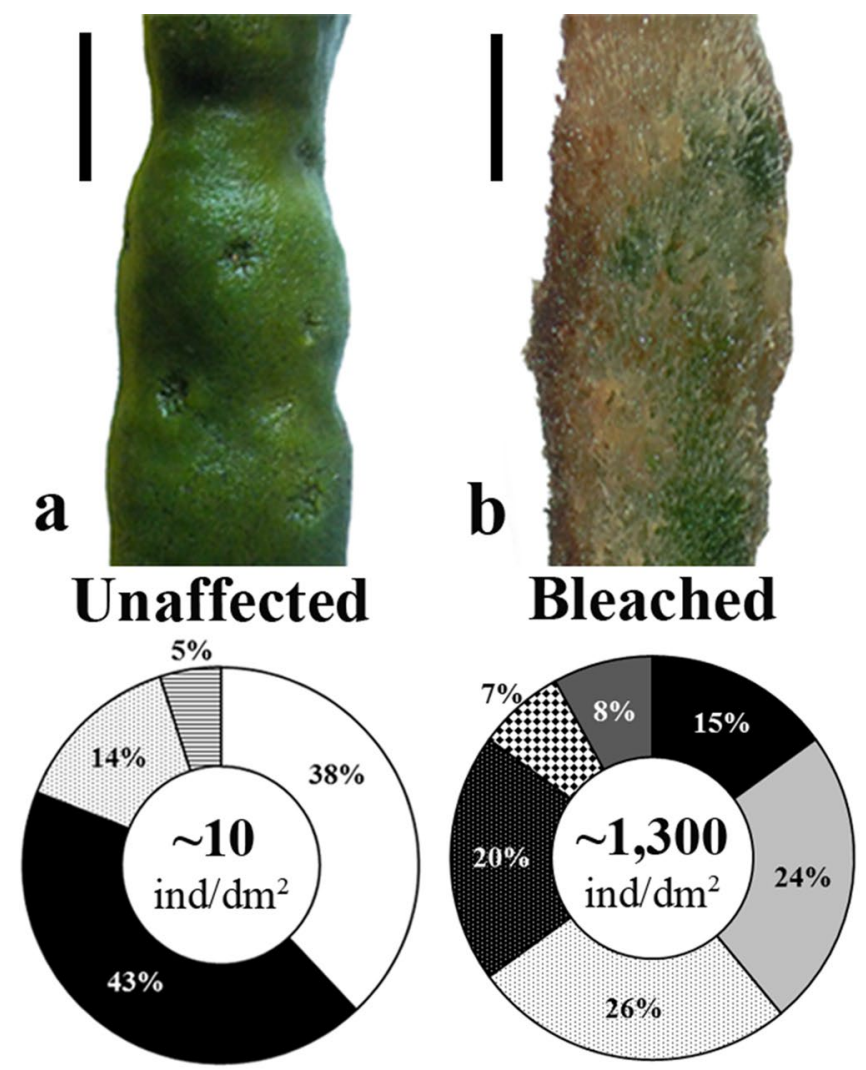

c

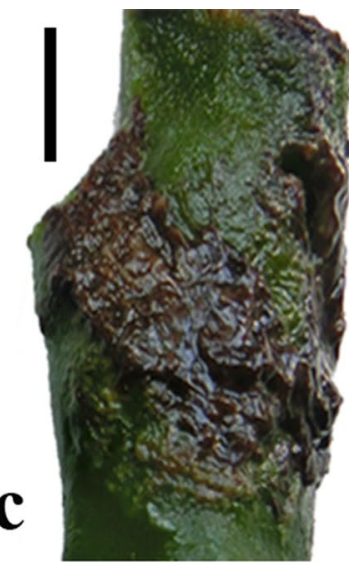

Covered by a fouling/biofilm

$\sim 9,800 \mathrm{ind} / \mathrm{dm}^{2}$

complexes of epizoic organisms were subdivided into four types
Oligochaeta

霸 nauplii of Copepoda
Tardigrada

Chironomidae
Harpacticoida

Others

\section{Infauna of diseased and dead L. baikalensis: density and composition}

Disease initially leads to a deterioration of the sponge body (decreased firmness due to tissue destruction), which presents an opportunity for a diverse and dense infaunal community to develop (Fig. 3). We assessed infaunal composition and abundance separately for each of three types of tissue damage in diseased sponges (Fig. 4). Unaffected fragments of diseased sponges harbored a small quantity of invertebrates $\left(10 \mathrm{ind} / \mathrm{dm}^{2}\right)$. Besides oligochaetes and nematodes, which dominated there, we also found Harpacticoida and Chironomidae (Table 1, Fig. 4a). In bleached fragments, the total number of invertebrates was $1303 \pm 441 \mathrm{ind} / \mathrm{dm}^{2}$. Dominant infaunal groups in sponges with that type of damage were Harpacticoida, Tardigrada, Cyclopoida, and Oligochaeta (Table 1, Fig. 4b). Additionally, nauplii of Copepoda (7\%), Rotifera, Nematoda, Chironomidae, Ostracoda, Cladocera, Turbellaria, and Amphipoda (juveniles $~ 3 \mathrm{~mm}$ long) contributed up to $15 \%$ of the infaunal abundance in total.

As a result, we observed that the spatial distribution of infauna in the diseased sponges was erratic and variable. Two factors contributed to this: (1) the heterogeneity of the surfaces of diseased sponge specimens, and (2) gradual decomposition of the sponge body. Therefore, in the unaffected fragments of diseased sponges, the density of infaunal organisms was minimal, just as it was in "healthy" L. baikalensis. In the bleached fragments, empty space appeared between the skeletal elements, along with a bulk of consumable food sources. This resulted in a 130-fold increase in the density of infauna present in the bleached tissue in comparison to that of "healthy" L. baikalensis. Thus, decay processes contributed to the development of rich communities of saprophages in the affected areas of the sponge body.

In fragments of diseased sponges covered with cyanobacterial/diatom foulings and biofilms, there were numerous animals within the damaged sponge body, but there were even more in the fouling matrix. The highest infaunal density $\left(9791 \pm 2732 \mathrm{ind} / \mathrm{dm}^{2}\right)$ occurred in these fragments (Fig. 4c). We subdivided these complexes of epizoic organisms into four types (Fig. 5). Distinct faunal assemblages varying in abundance and structure inhabited these complexes (Table 3 ). The invertebrate communities with the largest abundance $\left(18,293 \pm 5958 \mathrm{ind} / \mathrm{dm}^{2}\right)$ occurred in three complexes containing cyanobacteria, and were dominated numerically by nematodes. In biofilms formed mostly by diatom algae, however, the animal community was poorer in 

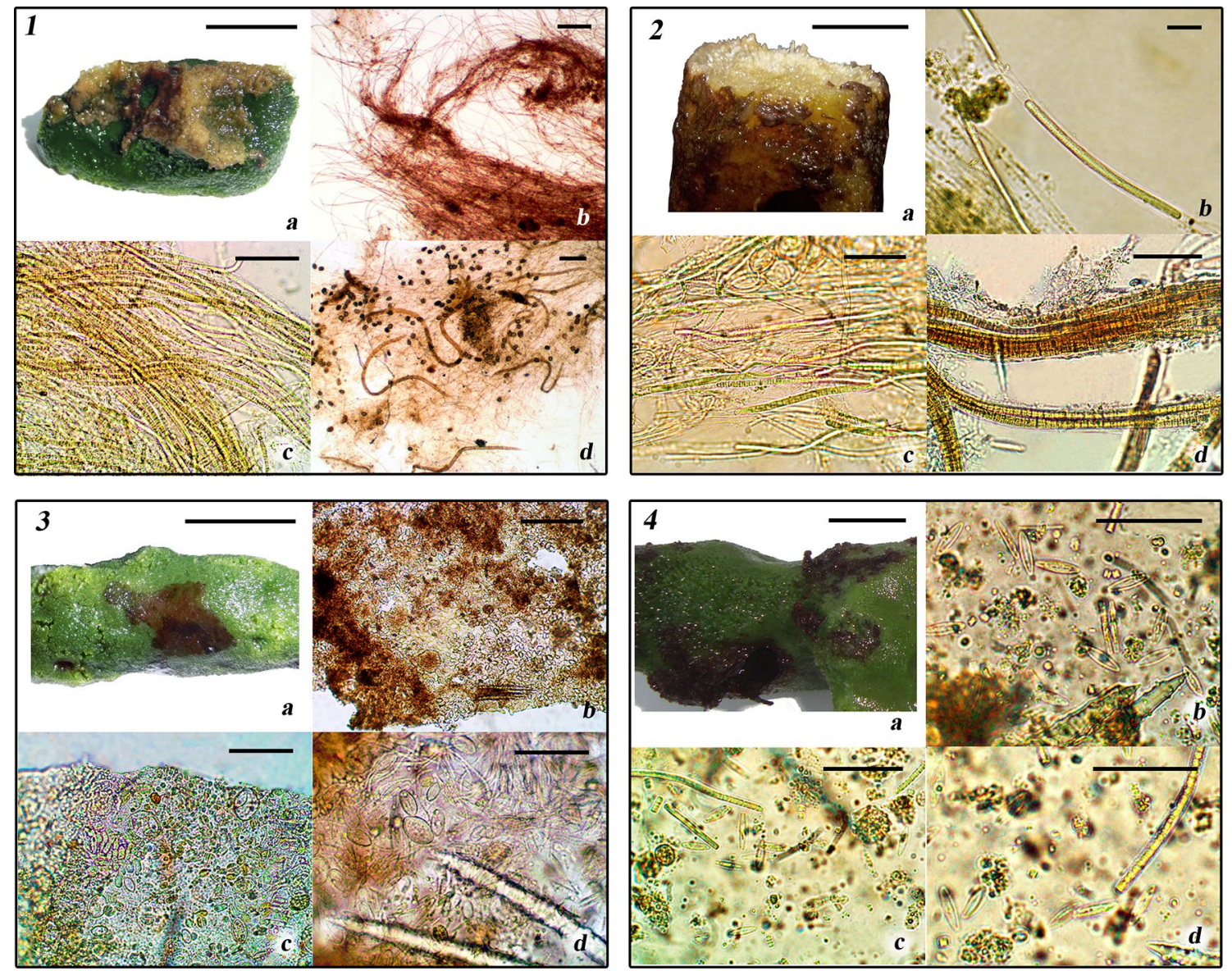

Fig. 5 Epizoic complexes of diseased sponges (L. baikalensis). 1 Filamentous cyanobacteria Tychonema sp. and a mixture of other cyanobacterial species ( $a$ sponge body covered by a fouling, $b$ filaments of Tychonema at $4 \times$ magnification, $c$ the same at $40 \times$ magnification, $d$ nematodes, their eggs, and tardigrades between the filaments at $4 \times$ magnification). 2 Filamentous cyanobacteria Phormidium aerugineocaeruleum (Gomont) Anagnostidis \& Komárek and Pseudanabaena galeata Böcher, Symplocastrum sp. ( $a$ sponge body covered by a fouling, $b$ filaments of Ph. aerugineo-caeruleum at $40 \times$ magnification, $c$

the same, $d$ filaments of Symplocastrum sp. at $40 \times$ magnification). 3 Diatom algae Cocconeis sp. and cyanobacteria Chamaesiphon fuscus (Rostafinski) Hansgirg ( $a$ sponge body covered by a biofilm, $b$ the biofilm at $4 \times$ magnification, $c$ the same at $40 \times$ magnification, $d$ the same). 4 Diatom algae and filamentous cyanobacteria Tychonema sp. ( $a$ sponge body covered by a biofilm, $b$ the biofilm at $40 \times$ magnification, $c, d$ the same). Scale bars: $1 a, 2 a, 3 a, 4 a: 1 \mathrm{~cm} ; \mathbf{1} b, \mathbf{1} d, \mathbf{3} b$ : $200 \mu \mathrm{m} ; \mathbf{1} c, \mathbf{2} c, \mathbf{2} d, \mathbf{3} c, \mathbf{3} d, \mathbf{4} b, \mathbf{4} c, \mathbf{4} d: 50 \mu \mathrm{m} ; \mathbf{2} b: 20 \mu \mathrm{m}$

Table 3 Invertebrate faunal assemblages and abundances in four different epizoic complexes on the surfaces of diseased sponges (L. baikalensis) collected from Lake Baikal in December 2015 through September 2016

\begin{tabular}{|c|c|c|c|}
\hline Complex type & Dominant algal species of epizoic complex & Fauna of complex & Total faunal abundance \\
\hline Fouling & $\begin{array}{l}\text { Filamentous cyanobacteria Tychonema sp. and } \\
\text { mixture of other cyanobacterial species }\end{array}$ & $\begin{array}{l}\text { Nematoda (95\% of the total abundance), Tardi- } \\
\text { grada (5\%), Oligochaeta, and Harpacticoida } \\
\text { (less than } 1 \%)\end{array}$ & $1200-54,414 \mathrm{ind} / \mathrm{dm}^{2}(N=6)$ \\
\hline Fouling & $\begin{array}{l}\text { Filamentous cyanobacteria } P h . \text { aerugineo-caer- } \\
\text { uleum and } P \text {. galeata, Symplocastrum sp. }\end{array}$ & $\begin{array}{l}\text { Nematoda (95\%), Rotifera, Tardigrada, } \\
\text { Cyclopoida, Oligochaeta (5\%) }\end{array}$ & $9942 \mathrm{ind} / \mathrm{dm}^{2}(N=1)$ \\
\hline Biofilm & $\begin{array}{l}\text { Diatom algae Cocconeis sp. (less often Gom- } \\
\text { phonema sp., Navicula sp.), and cyanobacte- } \\
\text { ria Ch. fuscus }\end{array}$ & $\begin{array}{l}\text { Harpacticoida (45\%), Tardigrada }(45 \%) \text {, } \\
\text { Chironomidae (7\%), Rotifera, Nematoda, } \\
\text { Oligochaeta, Turbellaria, Cyclopoida, Amphi- } \\
\text { poda, Ostracoda }(3 \%)\end{array}$ & $303-11,386 \mathrm{ind} / \mathrm{dm}^{2}(N=3)$ \\
\hline Biofilm & $\begin{array}{l}\text { Diatom algae and filamentous cyanobacteria } \\
\text { Tychonema sp. }\end{array}$ & Nematoda (100\%) & $9362-16,067 \mathrm{ind} / \mathrm{dm}^{2}(N=2)$ \\
\hline
\end{tabular}


number $\left(4502 \pm 2833 \mathrm{ind} / \mathrm{dm}^{2}\right)$ but consisted of more taxa, including tardigrades, harpacticoids, and chironomids.

The highest density of invertebrates was observed in epizoic complex I formed by Tychonema sp. and other cyanobacterial species, which covered the apical fragment of the sponge branch (September 2016, Chernaya Bay, see Fig. 5.1). Many nematodes $\left(49,296 \mathrm{ind} / \mathrm{dm}^{2}\right)$, along with their eggs, and tardigrades (5075 ind $/ \mathrm{dm}^{2}$ ) were observed within the dense interlacing of cyanobacterial filaments. We found that areas with cyanobacterial foulings of Tychonema sp. were preferred by infauna to biofilms consisting of the diatoms Cocconeis sp. and Ch. fuscus. We suggest that the highest density of nematodes occurs in foulings consisting of filamentous cyanobacteria. Omnivorous nematode genera (Tobrilus and Eutobrilus) dominated here, and they consume protozoans, diatoms, and fungal hyphae, with some species being carnivorous. The detritus-consuming (selective and nonselective) nematodes of the genera Monhystera and Ethmolaimus (Gagarin 2001) occurred more rarely.

It is noteworthy that biofilm complex III (Fig. 5.3) was present on sponges in Lake Baikal before their mass disease. Also, such biofilms were observed for epiphyton of Elodea canadensis Michx. and in experiments with steel plates in the littoral zone of Lake Baikal (Pomazkina et al. 2012; Sorokovikova et al. 2013). The diatom biofilms mentioned above develop in places where sponge branches touch a substrate or each other, forming a chitin-like crust on the sponge surface. Therefore, their development could be considered a natural process and not related to the mass disease of Baikalian sponges. Invertebrate communities inhabiting this complex could be regarded as common for healthy sponges.

Dead sponge fragments exhibited the highest grade of tissue degradation and had skeletal elements of a brownish color. In the dead sponges, animals inhabited the entire body of the decaying sponge, and they were able to penetrate from the surface deep into the sponge body. Invertebrate abundances in dead sponges ranged from 638 to $16,556 \mathrm{ind} / \mathrm{dm}^{2}$ (4767 ind $/ \mathrm{dm}^{2}$ on average). In dead L. baikalensis sponges, such taxonomic groups as nematodes, tardigrades, microturbellarians, and oligochaetes dominated (Table 1, Fig. 3). The remaining $12 \%$ of the total abundance was contributed by chironomids, large infusoria $(\sim 300 \mu \mathrm{m})$, cyclopoids, rotiferans, ostracods, cladocerans, and amphipods (juveniles) (Fig. 3). The invertebrate community in the dead sponge was distinguished by marked increases in the abundances of turbellarians and chironomids and the appearance of large infusoria. The latter group was not observed in the infauna of the "healthy" or diseased sponges.

The decaying body of a dead sponge becomes a "grand feast" for various saprophagous animals and bacteria, which play an active role in the sponge's decomposition. It is well known that bacterioflora, microdetritus particles (up to $15 \mu \mathrm{m}$ ), and tiny periphytic algae (green algae and diatoms) are primary food objects for the bdelloid rotiferans (Kutikova 2005) that were observed in diseased and dead sponges (Table 1). A large number of small multicellular organisms such as rotiferans may, in turn, attract carnivorous invertebrates (e.g., turbellarians, Chaetogaster oligochaetes). The bodies of the dead sponges were massively occupied by saprobic nematodes (genus Allodiplogaster), which inhabit any biotope characterized by a high concentration of decaying organic matter (Gagarin 2008). Also, omnivorous T. saprophagus was found in dead sponges along with the other bacterivorous nematodes Monhystera paludicola, Eumonhystera filiformis, and Ethmolaimus pilosus.

\section{Conclusions}

Deterioration and mass mortality of the endemic Lubomirskiidae sponges is ongoing in Lake Baikal. Ecologically, the Lubomirskiidae sponges play an essential role in the functioning of the Lake Baikal ecosystem. These filter feeders actively and efficiently clean large amounts of water, pumping it throughout their bodies. Baikalian sponges are highly important consumers of microplankton, especially bacteria. Clearly, the loss of endemic Baikalian sponges is an major conservation problem, but the loss of the natural filter these sponges provide will also greatly affect lake water quality and other endemic organisms.

Results of this study show that infauna is normally absent inside the bodies of "healthy" L. baikalensis sponges. The disease may make a large amount of food resources available for infaunal organisms, resulting in invertebrate communities that develop in affected sponge tissue. The subsequent death of L. baikalensis stimulates the formation of abundant saprophagous communities throughout the sponge. With the deterioration of the sponge body, the number of taxonomic groups increased sixfold, and invertebrate abundance increased 1000-fold. All these organisms are directly or indirectly processing organic matter. Some animals inhabit cyanobacteria or diatom foulings and biofilms, which tend to develop profusely on the surfaces of diseased sponges. Moreover, filamentous cyanobacteria harbor the most abundant infaunal communities, which are dominated by nematodes (up to $18,000 \mathrm{ind} / \mathrm{dm}^{2}$ ).

The striking increase in saprophagous invertebrates inhabiting diseased and dead sponges may also change the community structure of higher trophic levels such as macrobenthic invertebrates and fish in the nearshore zone, which may, in turn, alter the functioning of the coastal ecosystem of the entire lake.

Acknowledgements We gratefully thank the researchers of the Laboratory of Aquatic Invertebrate Biology, LIN SB RAS: Dr. N. Bukshuk (for consultation on Lubomirskiidae and reviewing the paper), Dr. E. 
Zaytseva (for identifying the planarian species), and Dr. A. Poberezhnaya and M. Gula (fieldwork assistance). Special thanks to the following SCUBA divers for underwater sampling: Dr. A. Kupchinsky, V. Chernykh, and Dr. I. Nebesnykh. We thank the editors and anonymous reviewers for their suggestions, which greatly improved the manuscript. The authors are very grateful to Prof. M. V. Moore (Dept. of Biological Sciences, Wellesley College, USA) for the English language editing. Financial support was provided by the following projects: sampling expeditions by the State Project of SB RAS no. 0345-2019-0009; determination of the species composition of foulings by the State Project of SB RAS no. 0345-2019-0003.

\section{References}

Belykh OI, Tikhonova IV, Kuzmin AV et al (2016) First detection of benthic cyanobacteria in Lake Baikal producing paralytic shellfish toxins. Toxicon 121:36-40. https://doi.org/10.1016/j.toxic on.2016.08.015

Belykh OI, Fedorova GA, Kuzmin AV et al (2017) Microcystins in cyanobacterial biofilms from the littoral zone of Lake Baikal. Mosc Univ Biol Sci Bull 72:225-231. https://doi.org/10.3103/ S0096392517040022

Bołtruszko JS, Ejsmont-Karabin J (2013) Epizoic communities of Rotifera inhabiting sponges in freshwaters of North-Eastern Poland. Ocean Hydrob Stud 42:46-50. https://doi.org/10.2478/ s13545-013-0062-2

Denikina NN, Dzyuba EV, Bel'kova NL et al (2016) The first case of disease of the sponge Lubomirskia baicalensis: investigation of its microbiome (in Russian). Biol Bull RAS 3:315-322. https:// doi.org/10.7868/S0002332916030024

Efremova SM (2001) Sponges (Porifera) (in Russian). In: Timoshkin $\mathrm{OA}$ et al (eds) Index of animal species inhabiting Lake Baikal and its catchment area, vol I. Book 1. Nauka, Novosibirsk, pp 179-192

Fusari LM, Oliveira CSN, Hamada H (2012) New species of Ablabesmyia Johannsen from the Neotropical region: first report of a sponge-dwelling Tanypodinae. Zootaxa 3239:43-50

Gagarin VG (2001) Svobodnozhivushie nematody presnykh vod Rossii i sopredelnykh stran: Fauna i puti eyo formirovaniya, ecologiya, taxonomiya, filogeniya (Free-living nematodes of freshwater bodies of Russia and neighboring countries: fauna and the ways of its developing, ecology, taxonomy, phylogeny). Nauka, Moscow (in Russian)

Gagarin VG (2008) Nematodes of the order Diplogasterida in the Russian Fauna. Nauka, Moscow (in Russian)

Gaino E, Lancioni T, La Porta G, Todini B (2004) The consortium of the sponge Ephydatia fluviatilis (L.) living on the common reed Phragmites australis in Lake Piediluco (central Italy). Hydrobiologia 520:165-178

Gugel J (2001) Life cycles and ecological interactions of freshwater sponges (Porifera, Spongillidae) in the River Rhine in Germany. Limnologica 31:185-198. https://doi.org/10.1016/S0075 $-9511(01) 80020-7$

Izmest'eva LR, Moore MV, Hampton SE et al (2016) Lake-wide physical and biological trends associated with warming in Lake Baikal. J Gt Lakes Res 42:6-17. https://doi.org/10.1016/j.jglr.2015.11.006

Kamaltynov RM, Chernykh VI, Slugina ZV, Karabanov EB (1993) The consortium of the sponge Lubomirskia baicalensis in Lake Baikal, East Siberia. Hydrobiologia 271:179-189

Khanaev IV, Kravtsova LS, Maikova OO et al (2018) Current state of the sponge fauna (Porifera: Lubomirskiidae) of Lake Baikal: sponge disease and the problem of conservation of diversity. J Gt Lakes Res 44:77-85. https://doi.org/10.1016/j.jglr.2017.10.004

Kharchenko TA, Lyashenko AV, Davydov OA (1989) Konsortsiya presnovodnoi gubki v kanale Dnepr-Donbass (Consortium of a freshwater sponge from channel Dnepr-Donbass) (in Russian). Gidrobiol Zh 25:31-35

Komárek J, Anagnostidis K (2005) Cyanoprokaryota-2. Teil: Oscillatoriales. In: Büdel BL, Krienitz G, Gärtner M, Schagerl M (eds) Süßwasserflora von Mitteleuropa, Band 19/2. Elsevier/Spektrum, Heidelberg, pp 1-759

Konopacka A, Siciński J (1985) Macrofauna inhabiting the colonies of the sponge Spongilla lacustris (L.) in the River Gać. Verh Internat Verein Limnol 22:2968-2973

Kozhov MM (1931) K poznaniyu fauny Baikala, eyo raspredeleniya i usloviy obitaniya (To the knowledge of the fauna of Lake Bai$\mathrm{kal}$, its distribution and conditions of habitation) (in Russian). Izvestiya Biologo-Geograficheskogo Nauchno-Issledovatel'skogo Instituta pri Irkutskom Universitete 5:3-171

Kozhov MM (1963) Lake Baikal and its life. Springer, Dordrecht

Kravtsova LS, Izhboldina LA, Khanaev IV et al (2014) Nearshore benthic blooms of filamentous green algae in Lake Baikal. J Gt Lakes Res 40:441-448. https://doi.org/10.1016/j.jglr.2014.02.019

Kulakova NV, Sakirko MV, Adelshin RV et al (2018) Brown rot syndrome and changes in the bacterial community of the Baikal sponge Lubomirskia baicalensis. Microb Ecol 75:1024-1034. https://doi.org/10.1007/s00248-017-1097-5

Kurashov EA (1994) Meiobenthos as a component of lake ecosystem. Alga-Fond, St. Petersburg (in Russian)

Kutikova LA (2005) Bdelloidnye kolovratki fauny Rossii (Bdelloid rotiferans of Russia). Tovaristchestvo nauchnykh izdaniy KMK, Moscow (in Russian)

Lazareva VI (1997) Mnogoletnie variatsii struktury zooplanktona Rybinskogo vodokhranilischa (Long-term variations in the structure of zooplankton of the Rybinsk reservoir) (in Russian). Water Resour 24:90-96

Leite FPP, Pavani L, Tanaka MO (2016) Temporal variation of epi- and endofaunal assemblages associated with the red sponge Tedania ignis on a rocky shore (São Sebastião Channel), SE Brazil. Iheringia Série Zoologia 106:1-8. https://doi.org/10.1590/1678-4766e 2016007

Mamontov AA, Mamontova EA, Tarasova EN, McLachlan MS (2000) Tracing the sources of PCDD/Fs and PCBs to Lake Baikal. Environ Sci Tech 34:741-747. https://doi.org/10.1021/es991047r

Manconi R, Pronzato R (2008) Global diversity of sponges (Porifera: Spongillina) in freshwater. Hydrobiologia 595:27-33. https://doi. org/10.1007/s10750-007-9000-x

Manconi R, Pronzato R (2015) Phylum Porifera. In: Thorp J, Rogers DC (eds) Ecology and general biology: Thorp and Covich's freshwater invertebrates, 4th edn. Elsevier, Amsterdam, pp 133-157

Moore MV, Hampton SE, Izmest'eva LR et al (2009) Climate change and the world's "Sacred Sea"-Lake Baikal, Siberia. Bioscience 59:405-417. https://doi.org/10.1525/bio.2009.59.5.8

Pomazkina G, Kravtsova L, Sorokovikova E (2012) Structure of epiphyton communities on Lake Baikal submerged macrophytes. Limnol Rev 12:19-27. https://doi.org/10.2478/v1019 4-011-0041-1

Rezvoy PD (1936) Freshwater sponges. Academy of Sciences of USSR, Moskva (in Russian)

Semernoy VP (2004) Oligochaeta of Lake Baikal. Nauka, Novosibirsk (in Russian)

Semiturkina NA, Efremova SM, Timoshkin OA (2009) State-of-theart of biodiversity and ecology of spongiofauna of Lake Baikal with special attention to the diversity, peculiarities of ecology, and vertical distribution of Porifera on Berezovy ecological test site (in Russian). In: Timoshkin OA et al (eds) Index of animal species inhabiting Lake Baikal and its catchment area: basins and channels in the South of East Siberia and North Mongolia, vol II. Book 1. Nauka, Novosibirsk, pp 891-901

Shitikov VK, Rozenberg GS, Zinchenko TD (2003) Kolichestvennaya gidroecologiya: metody sistemnoy identifikatsii (Quantitative 
hydroecology: system identification methods). IEVB RAN, Tolyatti (in Russian)

Sokolova AM, Palatov DM (2014) Macroinvertebrate assocations of sponges (Demospongiae: Spongillidae) from some fresh waters in the Palaearctic (in Russian). Povolzhskiy ecologicheskiy zhurnal 4:618-627

Sorokovikova EG, Belykh OI, Gladkikh AS et al (2013) Diversity of cyanobacterial species and phylotypes in biofilms from the littoral zone of Lake Baikal. J Microbiol 51:757-765. https://doi. org/10.1007/s12275-013-3240-4

Timoshkin OA, Malnik VV, Sakirko MV, Boedeker K (2014) Environmental crisis at Lake Baikal: scientists diagnose. Sci First Hand 5:75-91

Timoshkin OA, Samsonov DP, Yamamuro M et al (2016) Rapid ecological change in the coastal zone of Lake Baikal (East Siberia): is the site of the world's greatest freshwater biodiversity in danger? J Gt Lakes Res 42:487-497. https://doi.org/10.1016/j. jglr.2016.02.011

Timoshkin OA, Moore MV, Kulikova NN et al (2018) Groundwater contamination by sewage causes benthic algal outbreaks in the littoral zone of Lake Baikal (East Siberia). J Gt Lakes Res 44:230 244. https://doi.org/10.1016/j.jglr.2018.01.008
Trylis VV (1997) Soobschestva, associirovannye s presnovodnymi gubkami, kak faktor povysheniya bioraznoobraziya perifitona (Freshwater sponges associated communities as the factor of periphyton diversity increase) (in Russian). Abstract Book of the Conference “Збереження біорізноманітності в Україні”. Kiev, pp 53-55

Van Soest RWM, Boury-Esnault N, Hooper JNA et al (eds) (2012) World Porifera database. http://www.marinespecies.org/porifera. Accessed 02 Apr 2019

Weinberg I, Glyzina O, Weinberg E et al (2003) Types of interactions in consortia of baikalian sponges. Boll Mus Ist Biol Univ Genova 68:655-663

Zohary T, Ostrovsky I (2011) Ecological impacts of excessive water level fluctuations in stratified freshwater lakes. Inland Waters 1:47-59. https://doi.org/10.5268/IW-1.1.406

Publisher's Note Springer Nature remains neutral with regard to jurisdictional claims in published maps and institutional affiliations. 